\title{
Controlling myopia progression in children and adolescents
}

This article was published in the following Dove Press journal:

Adolescent Health, Medicine and Therapeutics

13 August 2015

Number of times this article has been viewed

\section{Molly J Smith \\ Jeffrey J Walline}

The Ohio State University College of Optometry, Columbus, $\mathrm{OH}$, USA

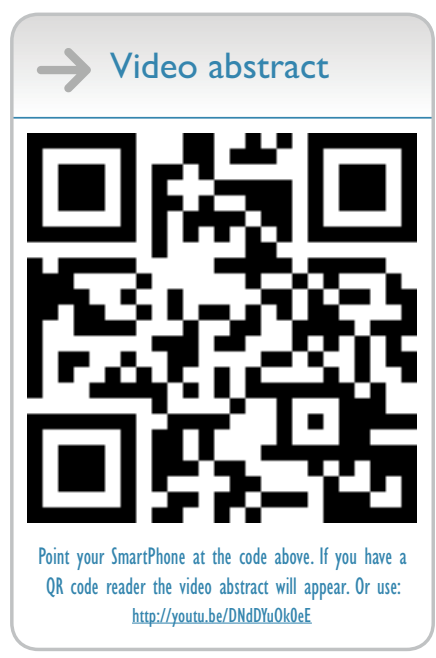

Correspondence: Jeffrey J Walline The Ohio State University College of Optometry, 338 West Tenth Avenue, Columbus, OH 43210-1240, USA

$\mathrm{Tel}+\mathrm{I} 6$ I4 2476840

Email walline.1@osu.edu
Abstract: Myopia is a common disorder, affecting approximately one-third of the US population and over $90 \%$ of the population in some East Asian countries. High amounts of myopia are associated with an increased risk of sight-threatening problems, such as retinal detachment, choroidal degeneration, cataracts, and glaucoma. Slowing the progression of myopia could potentially benefit millions of children in the USA. To date, few strategies used for myopia control have proven to be effective. Treatment options such as undercorrection of myopia, gas permeable contact lenses, and bifocal or multifocal spectacles have all been proven to be ineffective for myopia control, although one recent randomized clinical trial using executive top bifocal spectacles on children with progressive myopia has shown to decrease the progression to nearly half of the control subjects. The most effective methods are the use of orthokeratology contact lenses, soft bifocal contact lenses, and topical pharmaceutical agents such as atropine or pirenzepine. Although none of these modalities are US Food and Drug Administration-approved to slow myopia progression, they have been shown to slow the progression by approximately $50 \%$ with few risks. Both orthokeratology and soft bifocal contact lenses have shown to slow myopia progression by slightly less than $50 \%$ in most studies. Parents and eye care practitioners should work together to determine which modality may be best suited for a particular child. Topical pharmaceutical agents such as anti-muscarinic eye drops typically lead to light sensitivity and poor near vision. The most effective myopia control is provided by atropine, but is rarely prescribed due to the side effects. Pirenzepine provides myopia control with little light sensitivity and few near-vision problems, but it is not yet commercially available as an eye drop or ointment. Several studies have shown that lower concentrations of atropine slow the progression of myopia control with fewer side effects than $1 \%$ atropine. While the progression of myopic refractive error is slowed with lower concentration of atropine, the growth of the eye is not, indicating a potentially reversible form of myopia control that may diminish after discontinuation of the eye drops. This review provides an overview of the myopia control information available in the literature and raises questions that remain unanswered, so that eye care practitioners and parents can potentially learn the methods that may ultimately improve a child's quality of life or lower the risk of sight-threatening complications.

Keywords: myopia control, children, review, atropine, orthokeratology, soft bifocal contact lenses

\section{Introduction}

Myopia, also known as nearsightedness, is caused by an increase in eye length or corneal curvature and this condition causes light from distant objects to focus in front of the retina. Light focused in front of the retina results in blurry vision while looking at far away objects but clear vision while looking at close objects. 
Myopia affects approximately one-third of the US population, ${ }^{1}$ but the prevalence ranges from as low as $3 \%$ for Sherpa in $\mathrm{Nepal}^{2}$ to over $90 \%$ in Taiwan University students. ${ }^{3}$ In general, the prevalence of myopia is highest in Asian children, ${ }^{4-7}$ followed by Hispanic, and then black and white children. ${ }^{6,7}$ Some studies report a greater proportion of myopic females, ${ }^{8-11}$ but others report a similar prevalence between sexes. ${ }^{12-14}$ Myopia typically develops at approximately 8 years of age and progresses through 15 or 16 years of age, ${ }^{15,16}$ and the average rate of progression is approximately $0.50 \mathrm{D}$ (diopter) per year. ${ }^{17-20}$

Although myopia is a prevalent disease, little is known about the risk factors that lead to the development and progression of myopia. Genetics appear to play a role in determining a child's refractive error status. The risk of becoming myopic increases with the number of myopic parents, ${ }^{21-23}$ monozygotic twins have significantly stronger correlation of refractive error than dizygotic twins, ${ }^{24,25}$ and genetic factors are more responsible for variability in refractive error than environmental factors. ${ }^{26,27}$ However, no single chromosomal locus has been consistently associated with myopia. ${ }^{28-38}$ While near work has long been suspected to be a risk factor for myopia, few studies have found a strong correlation with either the onset or progression of myopia. ${ }^{21-23,39-41}$ However, spending more time outdoors has been shown to decrease the likelihood of becoming myopic, ${ }^{22,42-46}$ but does not slow down the progression of myopia. ${ }^{41,47}$ Some schools in Taiwan were randomly assigned to encourage outdoor activities during recess, while other schools maintained their normal routine during recess. In the schools that encouraged more outdoor activities during recess, only $8.4 \%$ of children became myopic, compared to $17.7 \%$ in the schools that maintained their normal recess activities $(P<0.001)$. However, the myopic children who were encouraged to spend time outdoors during recess progressed in myopia at the same rate as those who maintained their typical recess activities $(P=0.18) .{ }^{47}$

Higher amounts of myopia increase the risk of ocular complications such as glaucoma, ${ }^{48-51}$ cataracts, ${ }^{52-55}$ and retinal detachment and atrophy. ${ }^{56-60}$ Due to these sight-threatening complications and the high worldwide prevalence, research scientists have attempted many methods to reduce the progression of nearsightedness, including undercorrection of myopic refractive error, ${ }^{61,62}$ bifocal or multifocal spectacles, ${ }^{17,18,63-65}$ gas permeable contact lenses, ${ }^{19,66}$ topical pharmaceutical agents, ${ }^{67-73}$ orthokeratology contact lenses, ${ }^{74-79}$ and soft bifocal contact lenses. ${ }^{80-83}$

\section{Undercorrection of Myopia}

Myopes read more ${ }^{84,85}$ and scholastically perform better ${ }^{86,87}$ than emmetropes or hyperopes, so accommodative effort and myopia may be associated. Myopic patients also have a higher accommodative lag than emmetropic patients, ${ }^{88-91}$ and the lag of accommodation focuses light behind the retina during near work, potentially acting as a putative cue for increased myopia progression. Undercorrection of myopia reduces accommodative effort and accommodative error (lag), and hence is thought to slow myopia progression. In actuality, undercorrecting a child's refractive error either increases ${ }^{62}$ or has no effect on myopia progression, ${ }^{61}$ and so undercorrection does not slow myopia progression.

\section{Bifocal or multifocal spectacles}

A great deal of research has examined the effect of bifocal or multifocal spectacles on myopia progression. ${ }^{17,18,63-65}$ These glasses allow children to clearly see far away objects through the top portion of the spectacle lens. The bottom portion of the lens contains the reading power, which may control myopia progression by reducing or eliminating the accommodative effort or error associated with myopia. ${ }^{88-91}$ When compared to single vision lenses, bifocal or multifocal lenses slow the progression of myopia, but the difference in progression rates is typically not clinically meaningful..$^{17,18,64,65}$ Even myopic children believed to benefit most from bifocal or multifocal spectacle myopia control - those with esophoria (the resting position of the eyes is too close to the nose) and accommodative lag - do not exhibit clinically meaningful slowing of myopia progression. ${ }^{17,65}$ The most promising method of bifocal spectacle myopia control was reported by Cheng et al. ${ }^{63}$ They provided executive top bifocal spectacles and base-in prisms to children with progressing myopia and showed that the progression slowed by $51 \%$ over 3 years. The base-in prism did not result in additional treatment effect, but it is unknown whether they found a stronger treatment effect than other bifocal or multifocal spectacle myopia control studies because they utilized an executive top bifocal spectacle lens or because they only enrolled progressing myopes, which allowed for better myopia control. ${ }^{63}$

\section{Gas permeable contact lenses}

Alignment-fit gas permeable contact lenses worn during the day slowed myopia progression in early studies, but all those studies suffered from study design issues such as unequal loss to follow-up, enrollment of subjects outside of the expected age of progression, and lack of randomization. ${ }^{92-95}$ Two more recent randomized clinical trials showed that gas permeable 


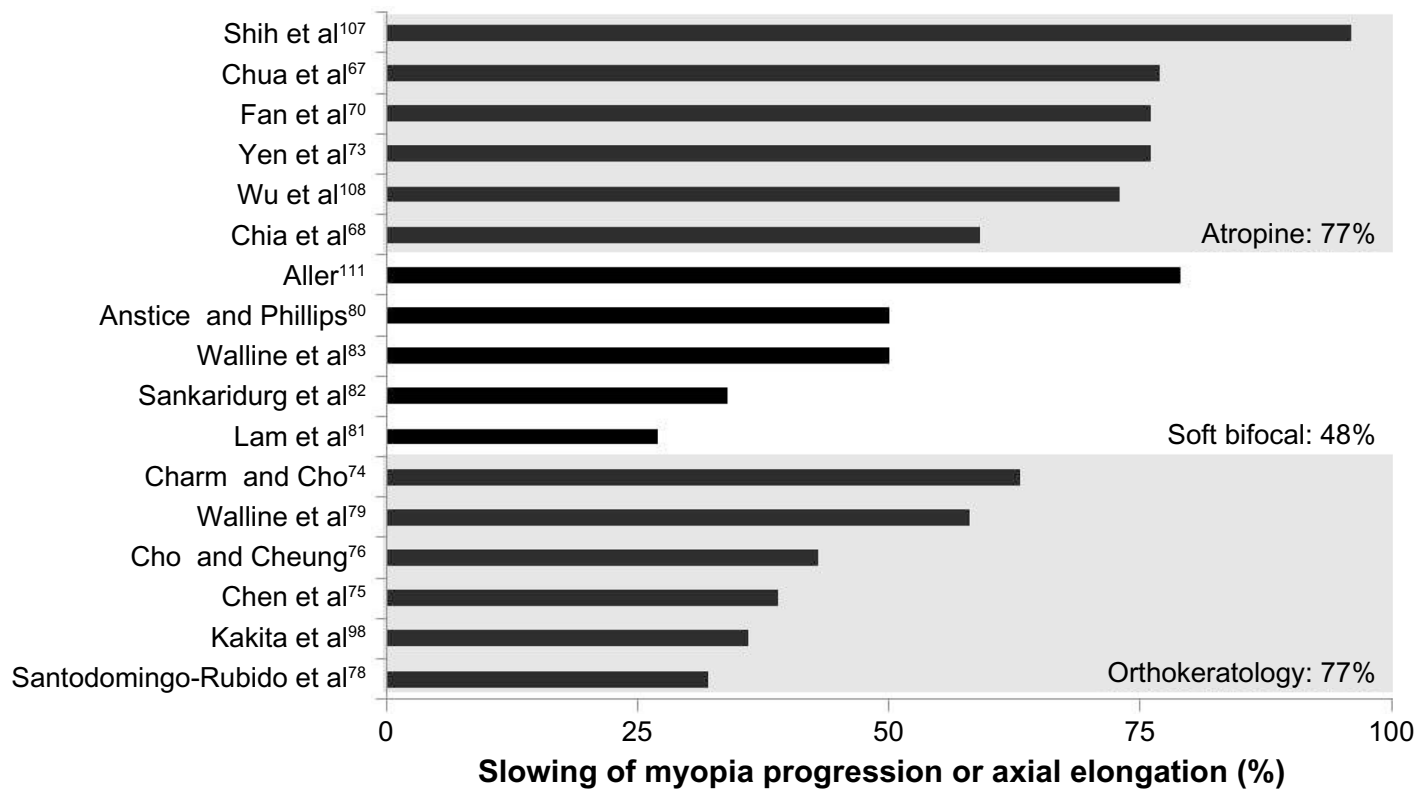

Figure I Percent slowing of myopia progression by atropine, soft bifocal, or orthokeratology contact lenses in controlled studies published in the literature. Notes: Percent slowing is calculated as the difference in progression between the experimental and control group, divided by the progression of the control group. The overall average for each type of correction is the simple mathematical average of the percent slowing for each study in that type of correction. Axial elongation was used when available, but myopia progression was used if axial elongation was not available.

contact lenses do not slow the growth of the eye. ${ }^{19,66}$ Although Walline et al reported significantly slower myopia progression in the gas permeable contact lens group, they found no difference in the eye growth. ${ }^{19}$ The treatment effect was mostly due to the differences in corneal curvature at the end of the study. Because corneal curvature changes are temporary, the slowed myopia progression is unlikely to be permanent, so the authors concluded that children should not be fitted with gas permeable contact lenses solely to slow the progression of myopia. ${ }^{19}$

In order to be considered clinically meaningful, a myopia control modality should slow the progression by approximately $50 \%$, according to most myopia control grant applications. Only three modalities are currently considered to be at least close to this level of myopia control: orthokeratology contact lenses, soft bifocal contact lenses, and topical pharmaceutical agents (Figure 1).

\section{Orthokeratology contact lenses}

Orthokeratology contact lenses are worn overnight to flatten the central cornea and temporarily reduce the amount of myopia. Orthokeratology contact lenses provide clear vision without the need for vision correction during the day, and they also reduce myopic progression (Table 1). ${ }^{74-79,96-98}$ These contact lenses are thought to slow myopia progression optically. Light that focuses in front of the retina (myopic blur) acts as a putative signal to slow the eye growth.
Orthokeratology contact lenses correct central refractive error while leaving peripheral myopic blur, which acts as a putative cue to slow the progression of myopia. ${ }^{98-100}$ Because these contact lenses are worn overnight, they are associated with an increased risk of microbial keratitis, which may be as high as wearing soft contact lenses overnight. ${ }^{101}$

Orthokeratology contact lenses slow axial length growth compared to single vision gas permeable contact lenses ${ }^{96}$ single vision soft contact lenses,${ }^{79}$ and single vision spectacles. ${ }^{74-76,97,98,102}$ The first randomized clinical trial of orthokeratology myopia control demonstrated significantly slower mean ( \pm standard deviation) axial elongation in children wearing orthokeratology lenses $(0.36 \pm 0.24 \mathrm{~mm})$ than children wearing single vision spectacles $(0.63 \pm 0.26 \mathrm{~mm}$, $P<0.01){ }^{76}$

\section{Soft bifocal contact lenses}

Soft bifocal contact lenses are typically worn by patients 40 years old or older to provide clearer vision while reading. Soft bifocal contact lenses with a center distance design (reading portion outside the central contact lens) also slow myopic progression by creating myopic defocus in the periphery, ${ }^{103}$ which acts as a putative signal to slow the eye growth. However, these lenses are worn during the day and fitted more commonly than orthokeratology contact lenses. Several nonrandomized, controlled clinical trials have shown the myopia control benefit of soft bifocal contact lenses. ${ }^{80-83}$ 
Table I Axial elongation of orthokeratology contact lens wearers compared to controls

\begin{tabular}{|c|c|c|c|c|c|}
\hline \multirow[t]{2}{*}{ Reference } & \multirow[t]{2}{*}{ Study design } & \multirow[t]{2}{*}{$\begin{array}{l}\text { Study duration } \\
\text { (years) }\end{array}$} & \multirow[t]{2}{*}{ Control method } & \multicolumn{2}{|c|}{$\begin{array}{l}\text { Mean change }( \pm S D) \text { in axial } \\
\text { length }(\mathrm{mm})\end{array}$} \\
\hline & & & & Orthokeratology & Control \\
\hline Charm and $\mathrm{Cho}^{74}$ & Randomized clinical trial & 2 & Single vision spectacles & $0.19 \pm 0.21$ & $0.5 \mathrm{I} \pm 0.32$ \\
\hline Chen et $\mathrm{al}^{75}$ & Self-selected prospective & 2 & Single vision spectacles & $0.31 \pm 0.27$ & $0.64 \pm 0.31$ \\
\hline Cho et $\mathrm{al}^{76}$ & Randomized clinical trial & 2 & Single vision spectacles & $0.36 \pm 0.24$ & $0.63 \pm 0.26$ \\
\hline Hiraoka et al ${ }^{97}$ & Self-selected retrospective & 5 & Single vision spectacles & $0.99 \pm 0.47$ & $\mathrm{I} .4 \mathrm{I} \pm 0.68$ \\
\hline Kakita et $\mathrm{al}^{98}$ & Self-selected retrospective & 2 & Single vision spectacles & $0.39 \pm 0.27$ & $0.6 \mathrm{I} \pm 0.24$ \\
\hline $\begin{array}{l}\text { Santodomingo-Rubido } \\
\text { et } \mathrm{al}^{78}\end{array}$ & Self-selected prospective & 2 & Single vision spectacles & 0.47 & 0.69 \\
\hline Swarbrick et $\mathrm{al}^{96}$ & $\begin{array}{l}\text { Randomized, contralateral } \\
\text { crossover }\end{array}$ & I & $\begin{array}{l}\text { Spherical gas permeable } \\
\text { contact lenses }\end{array}$ & $\begin{array}{l}0.02 \pm 0.09 \mathrm{~mm} \\
\text { in first } 6 \text { months }\end{array}$ & $\begin{array}{l}0.04 \pm 0.06 \mathrm{~mm} \\
\text { in first } 6 \text { months }\end{array}$ \\
\hline Walline et $\mathrm{al}^{79}$ & $\begin{array}{l}\text { Prospective, historical } \\
\text { controls }\end{array}$ & 2 & Soft contact lenses & $0.25 \pm 1.02$ & $0.57 \pm 1.12$ \\
\hline
\end{tabular}

Abbreviation: SD, standard deviation.

Overall, soft bifocal contact lenses slow the progression of myopia in children by nearly $50 \%$, which is similar to orthokeratology contact lenses (Table 2).

\section{Topical pharmaceutical agents}

Topical pharmaceutical methods to control myopic progression in children are anti-muscarinic eye drops that are used in routine eye care to dilate the pupil and reduce or eliminate accommodation. Atropine is a broad spectrum anti-muscarinic agent and side effects include temporary sensitivity to light and unclear vision at near. Pirenzepine affects only M1 anti-muscarinic receptors, which are less concentrated in the iris and ciliary body, and hence does not dilate the pupil or reduce accommodation as much as atropine.

Although the specific myopia control mechanism of anti-muscarinic agents is unknown, studies show both pirenzepine and atropine are very effective at reducing myopic eye growth in children (Table 3)..$^{70,71,73,104-108}$ However, atropine is rarely prescribed due to the side effects, and pirenzepine is not approved by the US Food and Drug Administration (FDA) for myopia control, nor is it commercially available.
Lower concentrations of atropine may provide clinically meaningful myopia control while minimizing side effects. ${ }^{68,69,71,107}$ Chia et al randomly assigned myopic children to $0.5 \%, 0.1 \%$, and $0.01 \%$ atropine eye drops ${ }^{68}$ Over 2 years, myopia progressed $-0.30 \pm 0.60 \mathrm{D}$ for the $0.5 \%$ group, $-0.38 \pm 0.60 \mathrm{D}$ for the $0.1 \%$ group, and $-0.49 \pm 0.63 \mathrm{D}$ for the $0.01 \%$ groups. All were significantly slower than the historical placebo control group. There was no difference between the groups in terms of best-corrected distance visual acuity, but the subjects with higher concentration of atropine had worse near visual acuity while wearing correction for distance vision. Subjects in this investigation were told that if they had trouble reading at near, they could request for reading glasses to help them see more clearly; $70 \%$ of children on $0.5 \%$ atropine, $61 \%$ of children on $0.1 \%$ atropine, and only $6 \%$ of children on $0.01 \%$ atropine requested the glasses to improve near vision. ${ }^{68}$ Although myopic progression was slowed by the lower concentration of eye drops, axial elongation of the eye was not. ${ }^{69}$ This result is puzzling and suggests that the myopia control may be due to changes in crystalline lens curvatures secondary to reduced tonic accommodation while the eyes are at rest. In fact, 1 year after discontinuation of the various concentrations of atropine eye drops, the most

Table 2 Changes in refractive error with soft bifocal contact lenses compared to single vision contact lens wearers

\begin{tabular}{|c|c|c|c|c|c|}
\hline \multirow[t]{2}{*}{ Reference } & \multirow[t]{2}{*}{ Study design } & \multirow[t]{2}{*}{ Study duration } & \multirow[t]{2}{*}{ Control method } & \multicolumn{2}{|c|}{$\begin{array}{l}\text { Mean }( \pm \mathrm{SE}) \text { spherical equivalent cycloplegic } \\
\text { refractive error }\end{array}$} \\
\hline & & & & Soft bifocal contact lens & Control \\
\hline Anstice and & Randomized, crossover & 20 months & Single vision contact lens & Period I: $-0.44 \pm 0.33$ & Period I: $-0.69 \pm 0.38$ \\
\hline Phillips ${ }^{80}$ & & & & Period 2: $-0.17 \pm 0.35$ & Period 2: $-0.38 \pm 0.38$ \\
\hline Lam et $\mathrm{al}^{81}$ & Randomized clinical trial & 2 years & Single vision contact lenses & $-0.59 \mathrm{D}$ & $-0.80 \mathrm{D}$ \\
\hline Sankaridurg et al ${ }^{82}$ & Prospective matched design & I year & Single vision spectacles & $-0.57 \mathrm{D}$ & $-0.86 \mathrm{D}$ \\
\hline Walline et $\mathrm{al}^{83}$ & Prospective matched design & 2 years & Single vision contact lenses & $-0.5 I \pm 0.06$ & $-1.03 \pm 0.06$ \\
\hline
\end{tabular}

Abbreviations: SE, standard error; D, diopter. 
Table 3 Effects of pharmaceutical agents on myopia progression compared to control groups

\begin{tabular}{|c|c|c|c|c|c|c|}
\hline \multirow[t]{2}{*}{ Reference } & \multirow[t]{2}{*}{ Study design } & \multirow[t]{2}{*}{$\begin{array}{l}\text { Study duration } \\
\text { (years) }\end{array}$} & \multirow[t]{2}{*}{ Treatment method } & \multirow[t]{2}{*}{$\begin{array}{l}\text { Control } \\
\text { method }\end{array}$} & \multicolumn{2}{|c|}{$\begin{array}{l}\text { Mean change }( \pm S D) \text { in } \\
\text { myopia progression }(D)\end{array}$} \\
\hline & & & & & Treatment & Control \\
\hline Fan et $\mathrm{al}^{70}$ & Interventional control & 1 & $1 \%$ atropine & No treatment & $+0.06 \pm 0.79$ & $-1.19 \pm 2.48$ \\
\hline Lee et $\mathrm{al}^{71}$ & Retrospective, case-control & I & $0.05 \%$ atropine & No treatment & $-0.28 \pm 0.26$ & $-0.75 \pm 0.35$ \\
\hline Shih et al ${ }^{107}$ & Randomized clinical trial & 2 & $\begin{array}{l}0.5 \%, 0.25 \%, 0.1 \% \\
\text { atropine }\end{array}$ & $0.5 \%$ tropicamide & $\begin{array}{l}0.5 \%:+0.04 \pm 0.63 \\
0.25 \%:-0.45 \pm 0.55 \\
0.1 \%:-0.47 \pm 0.9 \mid\end{array}$ & $-1.06 \pm 0.61$ \\
\hline $\begin{array}{l}\text { Siatkowski } \\
\text { et al }{ }^{105}\end{array}$ & Randomized clinical trial & 2 & $2 \%$ pirenzepine & Placebo & $-0.58 \pm 0.53$ & $-0.99 \pm 0.68$ \\
\hline Tan et al ${ }^{106}$ & Randomized clinical trial & I & $2 \%$ pirenzepine & Placebo & $-0.47 \pm 1.02$ & $-0.94 \pm 0.99$ \\
\hline Wu et al ${ }^{109}$ & Retrospective case-control & 3 & $0.1 \%$ atropine & No treatment & $-0.3 \mathrm{I} \pm 0.26$ & $-0.90 \pm 0.30$ \\
\hline Yen et $\mathrm{a}^{73}$ & Randomized clinical trial & 1 & $\begin{array}{l}\text { I\% atropine; |\% } \\
\text { cyclopentolate }\end{array}$ & Saline & $\begin{array}{l}\text { Atropine: } \\
-0.22 \pm 0.54 \\
\text { Cyclopentolate: } \\
-0.58 \pm 0.49\end{array}$ & $-0.91 \pm 0.58$ \\
\hline
\end{tabular}

Abbreviations: SD, standard deviation; D, diopter.

effective myopia control was provided by $0.01 \%$ atropine, ${ }^{69}$ presumably because the accommodative tonus returned to normal, negating the stronger myopia control effect due primarily to changes in tonic accommodation. In a separate study, $0.025 \%$ atropine was found to reduce the onset of myopia from $54 \%$ to $21 \%(P=0.016) .{ }^{110}$

The most effective myopia control was provided by topical pharmaceutical agents, but they are rarely prescribed due to the side effects. While lower concentrations provide clinically meaningful myopia control, the mechanism may be at least partially due to temporary changes in tonic accommodation and may not lead to permanent decreases in myopia progression.

\section{Conclusion}

Of all the methods studied to slow the progression of myopia, topical pharmaceutical agents, orthokeratology contact lenses, and soft bifocal contact lenses were found to be the most effective, commercially available modalities. However, none of them is approved by the FDA to slow the progression of myopia. Topical pharmaceuticals are not used frequently due to the side effects, primarily photophobia and reduced near vision and accommodation, but there is potential for myopia control with fewer side effects using lower concentrations. Orthokeratology contact lenses and soft bifocal contact lenses slow the myopic progression of myopia in a similar manner, so the best modality should be determined by the eye care practitioner and parent, based on the lifestyle of the specific child. Bifocal and multifocal spectacles is statistically significant in slowing the myopia progression, but do not provide a clinically meaningful effect; however, the latest randomized clinical trial using executive top bifocal spectacles on progressing myopes exhibited a clinically meaningful slowing of myopia progression. Undercorrection of myopia and gas permeable contact lenses were not found to slow the progression of myopia in children.

Although we have answered many questions about slowing of myopia progression in children, many questions remain to be answered. For example, will soft bifocal contact lenses with the reading portion in the center of the contact lenses also slow myopia progression? Will the implementation of both optical (soft bifocal or orthokeratology contact lenses) and pharmacologic (atropine) myopia control methods provide better myopia control than either one alone? Can we permanently reduce the risk of myopia onset using these myopia control methods? What happens to myopia progression once the myopia control modalities are discontinued? Far more research needs to be conducted to answer these important questions so that we can optimize eye care for children and potentially prevent or maintain lower amount of myopia, which may reduce the risk of sight-threatening complications.

\section{Disclosure}

The authors report no conflicts of interest in this work.

\section{References}

1. Vitale S, Ellwein L, Cotch MF, Ferris FL 3rd, Sperduto R. Prevalence of refractive error in the United States, 1999-2004. Arch Ophthalmol. 2008;126(8):1111-1119.

2. Garner LF, Owens H, Kinnear RF, Frith MJ. Prevalence of myopia in Sherpa and Tibetan children in Nepal. Optom Vis Sci. 1999;76(5):282-285.

3. Wang TJ, Chiang TH, Wang TH, Lin LL, Shih YF. Changes of the ocular refraction among freshmen in National Taiwan University between 1988 and 2005. Eye (Lond). 2009;23(5):1168-1169.

4. Ip JM, Huynh SC, Robaei D, et al. Ethnic differences in refraction and ocular biometry in a population-based sample of 11-15-year-old Australian children. Eye (Lond). 2008;22(5):649-656. 
5. Ip JM, Huynh SC, Robaei D, et al. Ethnic differences in the impact of parental myopia: findings from a population-based study of 12-year-old Australian children. Invest Ophthalmol Vis Sci. 2007; 48(6):2520-2528.

6. Kleinstein RN, Jones LA, Hullett S, et al. Refractive error and ethnicity in children. Arch Ophthalmol. 2003;121(8):1141-1147.

7. Voo I, Lee DA, Oelrich FO. Prevalences of ocular conditions among Hispanic, white, Asian, and black immigrant students examined by the UCLA Mobile Eye Clinic. J Am Optom Assoc. 1998;69(4):255-261.

8. Bar Dayan Y, Levin A, Morad Y, et al. The changing prevalence of myopia in young adults: a 13-year series of population-based prevalence surveys. Invest Ophthalmol Vis Sci. 2005;46(8):2760-2765.

9. Dandona R, Dandona L, Srinivas M, et al. Refractive error in children in a rural population in India. Invest Ophthalmol Vis Sci. 2002;43(3): $615-622$.

10. Hashemi H, Fotouhi A, Mohammad K. The age- and gender-specific prevalences of refractive errors in Tehran: the Tehran Eye Study. Ophthalmic Epidemiol. 2004;11(3):213-225.

11. He M, Huang W, Zheng Y, Huang L, Ellwein LB. Refractive error and visual impairment in school children in rural southern China. Ophthalmology. 2007;114(2):374-382.

12. Attebo K, Ivers RQ, Mitchell P. Refractive errors in an older population: the Blue Mountains Eye Study. Ophthalmology. 1999;106(6): 1066-1072.

13. Junghans BM, Crewther SG. Prevalence of myopia among primary school children in eastern Sydney. Clin Exp Optom. 2003;86(5):339-345.

14. Katz J, Tielsch JM, Sommer A. Prevalence and risk factors for refractive errors in an adult inner city population. Invest Ophthalmol Vis Sci. 1997;38(2):334-340.

15. Goss DA, Cox VD. Trends in the change of clinical refractive error in myopes. J Am Optom Assoc. 1985;56(8):608-613.

16. Thorn F, Gwiazda J, Held R. Myopia progression is specified by a double exponential growth function. Optom Vis Sci. 2005;82(4):286-297.

17. Fulk GW, Cyert LA, Parker DE. A randomized trial of the effect of single-vision vs bifocal lenses on myopia progression in children with esophoria. Optom Vis Sci. 2000;77(8):395-401.

18. Gwiazda J, Hyman L, Hussein M, et al. A randomized clinical trial of progressive addition lenses versus single vision lenses on the progression of myopia in children. Invest Ophthalmol Vis Sci. 2003;44(4): $1492-1500$.

19. Walline JJ, Jones LA, Mutti DO, Zadnik K. A randomized trial of the effects of rigid contact lenses on myopia progression. Arch Ophthalmol. 2004;122(12):1760-1766.

20. Walline JJ, Jones LA, Sinnott L, et al. Randomized trial of the effect of contact lens wear on self-perception in children. Optom Vis Sci. 2009;86(3):222-232.

21. Saw SM, Shankar A, Tan SB, et al. A cohort study of incident myopia in Singaporean children. Invest Ophthalmol Vis Sci. 2006;47(5): 1839-1844.

22. Jones LA, Sinnott LT, Mutti DO, Mitchell GL, Moeschberger ML, Zadnik K. Parental history of myopia, sports and outdoor activities, and future myopia. Invest Ophthalmol Vis Sci. 2007;48(8):3524-3532.

23. Mutti DO, Mitchell GL, Moeschberger ML, Jones LA, Zadnik K. Parental myopia, near work, school achievement, and children's refractive error. Invest Ophthalmol Vis Sci. 2002;43(12):3633-3640.

24. Dirani M, Chamberlain M, Shekar SN, et al. Heritability of refractive error and ocular biometrics: the Genes in Myopia (GEM) twin study. Invest Ophthalmol Vis Sci. 2006;47(11):4756-4761.

25. He M, Hur YM, Zhang J, Ding X, Huang W, Wang D. Shared genetic determinant of axial length, anterior chamber depth, and angle opening distance: the Guangzhou Twin Eye Study. Invest Ophthalmol Vis Sci. 2008;49(11):4790-4794.

26. Hammond CJ, Snieder H, Gilbert CE, Spector TD. Genes and environment in refractive error: the twin eye study. Invest Ophthalmol Vis Sci. 2001;42(6):1232-1236.
27. Lyhne N, Sjolie AK, Kyvik KO, Green A. The importance of genes and environment for ocular refraction and its determiners: a population based study among 20-45 year old twins. Br J Ophthalmol. 2001;85(12):1470-1476.

28. Chen CY, Stankovich J, Scurrah KJ, et al. Linkage replication of the MYP12 locus in common myopia. Invest Ophthalmol Vis Sci. 2007;48(10):4433-4439.

29. Ciner E, Ibay G, Wojciechowski R, et al. Genome-wide scan of AfricanAmerican and white families for linkage to myopia. Am J Ophthalmol. 2009; 147(3):512-517. e2.

30. Ciner E, Wojciechowski R, Ibay G, Bailey-Wilson JE, Stambolian D. Genomewide scan of ocular refraction in African-American families shows significant linkage to chromosome 7p15. Genet Epidemiol. 2008;32(5):454-463.

31. Hammond CJ, Andrew T, Mak YT, Spector TD. A susceptibility locus for myopia in the normal population is linked to the PAX6 gene region on chromosome 11: a genomewide scan of dizygotic twins. Am J Hum Genet. 2004;75(2):294-304.

32. Klein AP, Duggal P, Lee KE, Klein R, Bailey-Wilson JE, Klein BE. Confirmation of linkage to ocular refraction on chromosome 22q and identification of a novel linkage region on 1q. Arch Ophthalmol. 2007;125(1):80-85.

33. Mutti DO, Cooper ME, O'Brien S, et al. Candidate gene and locus analysis of myopia. Mol Vis. 2007;13:1012-1019.

34. Mutti DO, Semina E, Marazita M, Cooper M, Murray JC, Zadnik K. Genetic loci for pathological myopia are not associated with juvenile myopia. Am J Med Genet. 1, 2002;112(4):355-360.

35. Schache M, Richardson AJ, Mitchell P, et al. Genetic association of refractive error and axial length with $15 \mathrm{q} 14$ but not $15 \mathrm{q} 25$ in the Blue Mountains Eye Study cohort. Ophthalmology. 2013;120(2):292-297.

36. Schache M, Richardson AJ, Pertile KK, Dirani M, Scurrah K, Baird PN. Genetic mapping of myopia susceptibility loci. Invest Ophthalmol Vis Sci. 2007;48(11):4924-4929.

37. Wojciechowski R, Stambolian D, Ciner E, Ibay G, Holmes TN, Bailey-Wilson JE. Genomewide linkage scans for ocular refraction and meta-analysis of four populations in the Myopia Family Study. Invest Ophthalmol Vis Sci. 2009;50(5):2024-2032.

38. Zhu G, Hewitt AW, Ruddle JB, et al. Genetic dissection of myopia: evidence for linkage of ocular axial length to chromosome 5q. Ophthalmology. 2008;115(6):1053-1057. e2.

39. Richler A, Bear JC. Refraction, nearwork and education. A population study in Newfoundland. Acta Ophthalmol (Copenh). 1980;58(3): 468-478.

40. Angle J, Wissmann DA. The epidemiology of myopia. Am J Epidemiol. 1980;111(2):220-228.

41. Jones-Jordan LA, Sinnott LT, Cotter SA, et al. Time outdoors, visual activity, and myopia progression in juvenile-onset myopes. Invest Ophthalmol Vis Sci. 2012;53(11):7169-7175.

42. Dirani M, Tong L, Gazzard G, et al. Outdoor activity and myopia in Singapore teenage children. Br J Ophthalmol. 2009;93(8):997-1000.

43. Guggenheim JA, Northstone K, McMahon G, et al. Time outdoors and physical activity as predictors of incident myopia in childhood: a prospective cohort study. Invest Ophthalmol Vis Sci. 2012;53(6):2856-2865.

44. Jones-Jordan LA, Sinnott LT, Graham ND, et al. The contributions of near work and outdoor activity to the correlation between siblings in the Collaborative Longitudinal Evaluation of Ethnicity and Refractive Error (CLEERE) Study. Invest Ophthalmol Vis Sci. 2014;55(10):6333-6339.

45. Lin Z, Vasudevan B, Jhanji V, et al. Near work, outdoor activity, and their association with refractive error. Optom Vis Sci. 2014;91(4): 376-382.

46. Rose KA, Morgan IG, Ip J, et al. Outdoor activity reduces the prevalence of myopia in children. Ophthalmology. 2008;115(8):1279-1285.

47. Wu PC, Tsai CL, Wu HL, Yang YH, Kuo HK. Outdoor activity during class recess reduces myopia onset and progression in school children. Ophthalmology. 2013;120(5):1080-1085. 
48. Mitchell P, Hourihan F, Sandbach J, Wang JJ. The relationship between glaucoma and myopia: the Blue Mountains Eye Study. Ophthalmology. 1999;106(10):2010-2015.

49. Ponte F, Giuffre G, Giammanco R, Dardanoni G. Risk factors of ocular hypertension and glaucoma. The Casteldaccia Eye Study. Doc Ophthalmol. 1994;85(3):203-210.

50. Yoshida M, Okada E, Mizuki N, et al. Age-specific prevalence of openangle glaucoma and its relationship to refraction among more than 60,000 asymptomatic Japanese subjects. J Clin Epidemiol. 2001;54(11) 1151-1158.

51. Wong TY, Klein BE, Klein R, Knudtson M, Lee KE. Refractive errors, intraocular pressure, and glaucoma in a white population. Ophthalmology. 2003;10(1):211-217

52. Lim R, Mitchell P, Cumming RG. Refractive associations with cataract: the Blue Mountains Eye Study. Invest Ophthalmol Vis Sci. 1999;40(12):3021-3026.

53. McCarty CA, Mukesh BN, Fu CL, Taylor HR. The epidemiology of cataract in Australia. Am J Ophthalmol. 1999;128(4):446-465.

54. Wong TY, Klein BE, Klein R, Tomany SC, Lee KE. Refractive errors and incident cataracts: the Beaver Dam Eye Study. Invest Ophthalmol Vis Sci. 2001;42(7):1449-1454.

55. Younan C, Mitchell P, Cumming RG, Rochtchina E, Wang JJ. Myopia and incident cataract and cataract surgery: the Blue Mountains Eye Study. Invest Ophthalmol Vis Sci. 2002;43(12):3625-3632.

56. Curtin B. The Myopias: Basic Science and Clinical Management. Philadelphia, PA: Harper and Row, Publishers, Inc.; 1985.

57. Karlin DB, Curtin BJ. Peripheral chorioretinal lesions and axial length of the myopic eye. Am J Ophthalmol. 1976;81(5):625-635.

58. Pierro L, Camesasca FI, Mischi M, Brancato R. Peripheral retinal changes and axial myopia. Retina. 1992;12(1):12-17.

59. Celorio JM, Pruett RC. Prevalence of lattice degeneration and its relation to axial length in severe myopia. Am J Ophthalmol. 1991;111(1): 20-23.

60. Risk factors for idiopathic rhegmatogenous retinal detachment. The Eye Disease Case-Control Study Group. Am J Epidemiol. 1993;137(7): 749-757.

61. Adler D, Millodot M. The possible effect of undercorrection on myopic progression in children. Clin Exp Optom. 2006;89(5):315-321.

62. Chung K, Mohidin N, O'Leary DJ. Undercorrection of myopia enhances rather than inhibits myopia progression. Vision Res. 2002;42(22):2555-2559.

63. Cheng D, Woo GC, Drobe B, Schmid KL. Effect of bifocal and prismatic bifocal spectacles on myopia progression in children: three-year results of a randomized clinical trial. JAMA Ophthalmol. 2014;132(3):258-264.

64. Berntsen DA, Sinnott LT, Mutti DO, Zadnik K. A randomized trial using progressive addition lenses to evaluate theories of myopia progression in children with a high lag of accommodation. Invest Ophthalmol Vis Sci. 2012;53(2):640-649.

65. Correction of Myopia Evaluation Trial 2 Study Group for the Pediatric Eye Disease Investigator Group. Progressive-addition lenses versus single-vision lenses for slowing progression of myopia in children with high accommodative lag and near esophoria. Invest Ophthalmol Vis Sci. 2011;52(5):2749-2757.

66. Katz J, Schein OD, Levy B, et al. A randomized trial of rigid gas permeable contact lenses to reduce progression of children's myopia. Am J Ophthalmol. 2003;136(1):82-90.

67. Chua WH, Balakrishnan V, Chan YH, et al. Atropine for the treatment of childhood myopia. Ophthalmology. 2006;113(12):2285-2291.

68. Chia A, Chua WH, Cheung YB, et al. Atropine for the treatment of childhood myopia: safety and efficacy of $0.5 \%, 0.1 \%$, and $0.01 \%$ doses (Atropine for the Treatment of Myopia 2). Ophthalmology. 2012;119(2): 347-354.

69. Chia A, Chua WH, Wen L, Fong A, Goon YY, Tan D. Atropine for the treatment of childhood myopia: changes after stopping atropine $0.01 \%$, 0.1\% and 0.5\%. Am J Ophthalmol. 2014;157(2):451-457. e1.
70. Fan DS, Lam DS, Chan CK, Fan AH, Cheung EY, Rao SK. Topical atropine in retarding myopic progression and axial length growth in children with moderate to severe myopia: a pilot study. Jpn J Ophthalmol. 2007;51(1):27-33.

71. Lee JJ, Fang PC, Yang IH, et al. Prevention of myopia progression with 0.05\% atropine solution. J Ocul Pharmacol Ther. 2006;22(1):41-46.

72. Tong L, Huang XL, Koh AL, Zhang X, Tan DT, Chua WH. Atropine for the treatment of childhood myopia: effect on myopia progression after cessation of atropine. Ophthalmology. 2009;116(3):572-579.

73. Yen MY, Liu JH, Kao SC, Shiao CH. Comparison of the effect of atropine and cyclopentolate on myopia. Ann Ophthalmol. 1989;21(5): 180-182, 187

74. Charm J, Cho P. High myopia-partial reduction ortho-k: a 2-year randomized study. Optom Vis Sci. 2013;90(6):530-539.

75. Chen C, Cheung SW, Cho P. Myopia control using toric orthokeratology (TO-SEE study). Invest Ophthalmol Vis Sci. 2013;54(10):6510-6517.

76. Cho P, Cheung SW. Retardation of myopia in Orthokeratology (ROMIO) study: a 2-year randomized clinical trial. Invest Ophthalmol Vis Sci. 2012;53(11):7077-7085.

77. Cho P, Cheung SW, Edwards M. The longitudinal orthokeratology research in children (LORIC) in Hong Kong: a pilot study on refractive changes and myopic control. Curr Eye Res. 2005;30(1):71-80.

78. Santodomingo-Rubido J, Villa-Collar C, Gilmartin B, Gutierrez-Ortega R. Myopia control with orthokeratology contact lenses in spain (MCOS): refractive and biometric changes. Invest Ophthalmol Vis Sci. 2012; 53(8):5060-5065.

79. Walline JJ, Jones LA, Sinnott LT. Corneal reshaping and myopia progression. Br J Ophthalmol. 2009;93(9):1181-1185.

80. Anstice NS, Phillips JR. Effect of dual-focus soft contact lens wear on axial myopia progression in children. Ophthalmology. 2011;118(6): 1152-1161.

81. Lam CS, Tang WC, Tse DY, Tang YY, To CH. Defocus Incorporated Soft Contact (DISC) lens slows myopia progression in Hong Kong Chinese schoolchildren: a 2-year randomised clinical trial. Br J Ophthalmol. 2014;98(1):40-45

82. Sankaridurg P, Holden B, Smith E 3rd, et al. Decrease in rate of myopia progression with a contact lens designed to reduce relative peripheral hyperopia: one-year results. Invest Ophthalmol Vis Sci. 2011;52(13):9362-9367.

83. Walline JJ, Greiner KL, McVey ME, Jones-Jordan LA. Multifocal contact lens myopia control. Optom Vis Sci. 2013;90(11):1207-1214.

84. Grisham JD, Simons HD. Refractive error and the reading process: a literature analysis. J Am Optom Assoc. 1986;57(1):44-55.

85. Grosvenor T. Are visual anomalies related to reading ability? J Am Optom Assoc. 1977;48(4):510-517.

86. Williams SM, Sanderson GF, Share DL, Silva PA. Refractive error, IQ and reading ability: a longitudinal study from age seven to 11. Dev Med Child Neurol. 1988;30(6):735-742.

87. Simons HD, Gassler PA. Vision anomalies and reading skill: a metaanalysis of the literature. Am J Optom Physiol Opt. 1988;65(11): 893-904.

88. Mutti DO, Mitchell GL, Hayes JR, et al. Accommodative lag before and after the onset of myopia. Invest Ophthalmol Vis Sci. 2006; 47(3):837-846.

89. Nakatsuka C, Hasebe S, Nonaka F, Ohtsuki H. Accommodative lag under habitual seeing conditions: comparison between myopic and emmetropic children. Jap J Ophthalmol. 2005;49(3):189-194.

90. Gwiazda J, Bauer J, Thorn F, Held R. A dynamic relationship between myopia and blur-driven accommodation in school-aged children. Vision Res. 1995;35(9):1299-1304.

91. Gwiazda J, Thorn F, Bauer J, Held R. Myopic children show insufficient accommodative response to blur. Invest Ophthalmol Vis Sci. 1993;34(3):690-694.

92. Keller J. Myopia control with RGPs in children. Cont Lens Spect. 1996;11:45-48.

93. Khoo CY, Chong J, Rajan U. A 3-year study on the effect of RGP contact lenses on myopic children. Singapore Med J. 1999;40(4):230-237. 
94. Perrigin J, Perrigin D, Quintero S, Grosvenor T. Silicone-acrylate contact lenses for myopia control: 3-year results. Optom Vis Sci. 1990;67(10):764-769.

95. Stone J. The possible influence of contact lenses on myopia. $\mathrm{Br} J$ Physiol Opt. 1976;31(3):89-114.

96. Swarbrick HA, Alharbi A, Watt K, Lum E, Kang P. Myopia control during orthokeratology lens wear in children using a novel study design. Ophthalmology. 2015;122(3):620-630.

97. Hiraoka T, Kakita T, Okamoto F, Takahashi H, Oshika T. Long-term effect of overnight orthokeratology on axial length elongation in childhood myopia: a 5-year follow-up study. Invest Ophthalmol Vis Sci. 2012;53(7):3913-3919.

98. Kakita T, Hiraoka T, Oshika T. Influence of overnight orthokeratology on axial elongation in childhood myopia. Invest Ophthalmol Vis Sci. 2011;52(5):2170-2174.

99. Smith EL, Hung LF, Harwerth RS. Effects of optically induced blur on the refractive status of young monkeys. Vision Res. 1994;34(3): 293-301.

100. Troilo D, Wallman J. The regulation of eye growth and refractive state: an experimental study of emmetropization. Vision Res. 1991;31(7-8): 1237-1250.

101. Bullimore MA, Sinnott LT, Jones-Jordan LA. The risk of microbial keratitis with overnight corneal reshaping lenses. Optom Vis Sci. 2013;90(9):937-944.

102. Santodomingo-Rubido J,Villa-CollarC, Gilmartin B, Gutierrez-Ortega R. Myopia control with orthokeratology contact lenses in Spain: refractive and biometric changes. Invest Ophthalmol Vis Sci. 2012;53(8):5060-5065.

103. Ticak A, Walline JJ. Peripheral optics with bifocal soft and corneal reshaping contact lenses. Optom Vis Sci. 2013;90(1):3-8.
104. Siatkowski RM, Cotter S, Miller JM, et al. Safety and efficacy of $2 \%$ pirenzepine ophthalmic gel in children with myopia: a 1-year, multicenter, double-masked, placebo-controlled parallel study. Arch Ophthalmol. 2004;122(11):1667-1674.

105. Siatkowski RM, Cotter SA, Crockett RS, et al. Two-year multicenter, randomized, double-masked, placebo-controlled, parallel safety and efficacy study of $2 \%$ pirenzepine ophthalmic gel in children with myopia. J AAPOS. 2008;12(4):332-339.

106. Tan DT, Lam DS, Chua WH, Shu-Ping DF, Crockett RS, Asian Pirenzepine Study G. One-year multicenter, double-masked, placebocontrolled, parallel safety and efficacy study of $2 \%$ pirenzepine ophthalmic gel in children with myopia. Ophthalmology. 2005;112(1):84-91.

107. Shih YF, Chen CH, Chou AC, Ho TC, Lin LL, Hung PT. Effects of different concentrations of atropine on controlling myopia in myopic children. J Ocul Pharmacol Ther. 1999;15(1):85-90.

108. Wu PC, Yang YH, Fang PC. The long-term results of using lowconcentration atropine eye drops for controlling myopia progression in schoolchildren. J Ocul Pharmacol Ther. 2011;27(5):461-466.

109. Wu PC, Yang YH, Fang PC. The long-term results of using lowconcentration atropine eye drops for controlling myopia progression in schoolchildren. J Ocul Pharmacol Ther. 2011;27(5):461-466.

110. Fang PC, Chung MY, Yu HJ, Wu PC. Prevention of myopia onset with $0.025 \%$ atropine in premyopic children. J Ocul Pharmacol Ther. 2010;26(4):341-345.

111. Aller T, Wildsoet C. Results of a one-year prospective clinical trial (CONTROL) of the use of bifocal soft contact lenses to control myopia progression. Ophthalmic Physiol Opt. 2006;26:8-9.
Adolescent Health, Medicine and Therapeutics

\section{Publish your work in this journal}

Adolescent Health, Medicine and Therapeutics is an international, peer-reviewed, open access journal focusing on health, pathology, and treatment issues specific to the adolescent age group. All aspects of health maintenance, preventative measures and disease treatment interventions are addressed within the journal and practitioners from

\section{Dovepress}

all disciplines are invited to submit their work as well as healthcare researchers and patient support groups.. The manuscript management system is completely online and includes a very quick and fair peerreview system. Visit http://www.dovepress.com/testimonials.php to read real quotes from published authors. 